Przegląd Prawa Konstytucyjnego

----ISSN 2082-1212-----

DOI 10.15804/ppk.2021.06.45

-----2021, No. 6 (64)-----

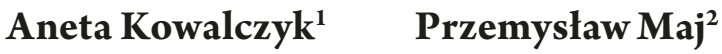

\section{Mediation as an Instrument of Social Dialogue}

Keywords: Industrial dispute, peaceful dispute resolution methods, mediation, mediator, agreement

Słowa kluczowe: Spór zbiorowy, pokojowe metody rozwiązywania sporów, mediacja, mediator, porozumienie

\begin{abstract}
Disputes are inherent in social relations, so the role of the legislator is to introduce rules under which they can be resolved. The methods that make it possible to resolve them include ADR methods. Mediation as an alternative form of dispute resolution has been known since antiquity, nowadays its precursor is the United States of America, where at the turn of the 1970s and 1980s alternative methods of conflict resolution were developed. Mediation, next to bargaining and social arbitration, is one of the peaceful methods of solving collective labour disputes. It should be stressed that as a peaceful method of resolving collective disputes, it can be treated as one of the instruments of social dialogue. Dialogue is an inmamental feature of dispute resolution regardless of its typology, and in the case of collective disputes it can be a guarantor of the preservation of social peace. Hence, it is very important to create a legal framework and introduce instruments to increase its effectiveness.

1 ORCID ID: 0000-0002-5029-863X, Assoc. Prof., Department of Labour and Social Insurance Law, Institute of Legal Sciences, College of Social Sciences, University of Rzeszow. E-mail: apaszek@ur.edu.pl.

2 ORCID ID: 0000-0002-5151-5464, Assoc. Prof., Department of Political Thought and Theory of Politics, Institute of Political Sciences, College of Social Sciences, University of Rzeszow.E-mail:pmaj@ur.edu.pl.
\end{abstract}




\section{Streszczenie}

\section{Mediacja jako instrument dialogu społecznego}

Spory są wpisane w stosunki społeczne, zatem rolą ustawodawcy jest wprowadzenie przepisów, w oparciu o które mogą byś rozwiązywane. Metodami umożliwiającymi ich rozwiązywanie, są między innymi metody ADR. Mediacja jako alternatywna forma rozwiązywania sporów znana była już w starożytności, współcześnie za jej prekursora uznaje się Stany Zjednoczone Ameryki Północnej, gdzie na przełomie lat siedemdziesiątych i osiemdziesiątych XX w. rozwinęły się alternatywne metody rozwiązywania konfliktów. Mediacja obok rokowań i arbitrażu społecznego jest jedną z pokojowych metod rozwiązywania sporów zbiorowych pracy. Należy podkreślić, że jako pokojowa metoda rozwiązywania sporów zbiorowych, może być traktowana jako jeden z instrumentów dialogu społecznego. Dialog jest inmamentną cechą rozwiązywania sporów niezależnie od ich typologii, a w przypadku sporów zbiorowych może być gwarantem zachowania pokoju społecznego. Stąd też bardzo duże znaczenie ma stworzenie ram prawnych i wprowadzenie instrumentów zwiększających jego skuteczność.

Mediation as an alternative form of dispute resolution has been known since antiquity, but its forerunner in modern times is considered to be the United States of America, where alternative methods of conflict resolution developed in the late 1970s and early $1980 \mathrm{~s}^{3}$. It is defined in the literature as "a structured process in which an impartial mediator helps those involved in a dispute to communicate so that they can better understand each other and reach mutually acceptable solutions"4. The essence of mediation as an alternative method for resolving collective disputes is therefore the participation of a third party in resolving the conflict, but the mediator's task is to mediate "in

3 E. Gmurzyńska, Mediacja w sprawach cywilnych w amerykańskim systemie prawnym zastosowanie w Europie i $w$ Polsce, Warsaw 2006, p. 5; A. Bieliński, Uwagi wstępne na temat mediacji [in:] Sądy polubowne i mediacja, ed. J. Olszewski, Warsaw 2008, p. 37; A. Kalisz, A. Zienkiewicz, Mediacja sądowa i pozasądowa. Zarys wykładu, Warsaw 2009, p. 26.

4 N. Doherty, M. Guyler, Mediacja i rozwiązywanie konfliktów w pracy, Warsaw 2010, p. 19. 
the communication of the parties and their reaching of an agreement, trying through rational persuasion to eliminate the discrepancies between the parties", but he cannot admit that any of the parties is right ${ }^{5}$. His task is therefore to propose solutions and not to settle the dispute, as he is not an arbitrator ${ }^{6}$.

Mediation, alongside bargaining and social arbitration, is one of the peaceful methods of resolving collective labour disputes. Mediation is the second stage of the peaceful resolution of collective disputes ${ }^{7}$. It takes place when the parties fail to reach an agreement at the stage of negotiations and the entity that initiated a collective dispute maintains its demands. It should be stressed, however, that as a peaceful method of resolving collective disputes, it can be treated as one of the instruments of social dialogue. Dialogue is an important feature of dispute resolution, regardless of its typology, and in the case of collective disputes, it can be a guarantor for the preservation of social peace.

Mediation is a stage constituting a continuation of the collective dispute, therefore the trade union organisation has no right to make additional demands ${ }^{8}$. It follows from Article 10 of the Act on Resolution of Collective Disputes that in the event that the party initiating the collective dispute upholds its earlier demands, the dispute is continued "with the participation of a per-

5 A. Kalisz, A. Zienkiewicz, op.cit., p. 33.

6 A. Wach, Delimitacja mediacji i koncyliacji jako samodzielnych form ARD, "Radca Prawny” 2005, No. 2, p. 95, A. Wach, Alternatywne formy rozwiązywania sporów sportowych, Warsaw 2005, p. 217, Z. Kmieciak, Mediacja i koncyliacja w prawie administracyjnym, Kraków 2004, p. 27, R. Morek, Razem czy osobno: uwagi o znaczeniu pojęć mediacji i koncyliacji [in:] Sądy polubowne..., p. 21, A. Kowalczyk, Mediacja jako przykład pokojowej metody rozwiazywania sporów zbiorowych, [in:] Aktualne zagadnienia prawa pracy i polityki socjalnej (zbiór studiów), ed. B.M. Ćwiertniak, Sosnowiec 2013, p. 211, Ł. Pisarczyk, Spory zbiorowe [in:] System prawa pracy, t. V: Zbiorowe prawo pracy, ed. K.W. Baran, Warsaw 2014, p. 592.

Law of May 23, 1991 on resolution of collective disputes (consol. text: Dz.U. 2015, item 295). A. Kowalczyk, Pojęcie sporu zbiorowego oraz pokojowe metody jego rozwiazywania w prawie polskim, Rzeszów 2017, p. 121-134, idem, Mediacja i arbitraż jako pokojowe metody rozwiązywania sporów zbiorowych pracy [in:] Arbitraż i mediacja. Aktualne problemy teorii i praktyki funkcjonowania sądów polubownych i ośrodków mediacyjnych, Rzeszów 2009, p. 187, A. Żurawska, Mediacja jako nowa metoda rozwiązywania sporów z zakresu prawa pracy, [in:] Sądy polubowne..., p. 101, B. Cudowski, Model rozwiązywania sporów zbiorowych, [in:] Zbiorowe prawo pracy w spotecznej gospodarce rynkowej, ed. G. Goździewicz, Toruń 2000, p. 246, 247, W. Masewicz, Zatarg zbiorowy pracy, Bydgoszcz 1994, p. 133.

8 A.M. Świątkowski, Ustawa o rozwiązywaniu sporów zbiorowych [in:] Zbiorowe prawo pracy. Komentarz, eds. J. Wratny, K. Walczak, Warsaw 2009, p. 338. 
son providing a guarantee of impartiality, hereinafter referred to as the mediator". However, the legislator does not specify when the demands submitted earlier are to be upheld. Article 9 of the above-cited Act provides that if the parties fail to reach an agreement, the negotiations shall end with the drawing up of a record of differences. However, it does not seem that it is equivalent to maintaining the demands submitted earlier, because from the theoretical point of view it may happen that the trade union party withdraws from the collective dispute. For this reason it seems necessary to confirm the trade union's desire to continue the dispute, which should take place after the first stage of resolving collective disputes has been completed, and only then can the mediator join the dispute. There do not appear to be any grounds for claiming that this may take place even before the end of the negotiations ${ }^{9}$.

The mediator is chosen jointly by the parties to the collective dispute, according to the rules established by them, as the legislator has not introduced any detailed regulations in this respect. The mediator may be anyone the parties to the collective dispute choose. This choice means that the mediator enjoys the trust of the parties and is therefore entrusted with conducting the mediation proceedings. This does not mean, however, that anyone can be a mediator without exception. The parties to an industrial dispute will undoubtedly place their trust in a person who, in addition to being impartial, has, in their view, competences that increase the likelihood of reaching an agreement. We must agree with the view expressed in the doctrine that mediation is a social function, or even a mission ${ }^{10}$. Accordingly, the choice of mediator cannot be arbitrary, since the likelihood of concluding an agreement ending a collective dispute depends on his skills and knowledge. The mediator should therefore have knowledge of psychology and expertise in the area of the collective dispute ${ }^{11}$. As it is accepted in the literature that mediation is above all about listening, this is one of the basic requirements for a mediator ${ }^{12}$. This

W. Masewicz, Ustawa o związkach zawodowych. Ustawa o rozwiąywaniu sporów zbiorowych, Warsaw 1998, p. 171; A.M. Świątkowski, op.cit., p. 338.

10 A. Kowalczyk, Rola mediatora w sporach zbiorowych [in] Prawo pracy. Refleksje i poszukiwania. Księga Jubileuszowa Profesora Jerzego Wratnego, ed. G. Uścińska, Warsaw 2013, p. 323, W. Masewicz, Ustawa o związkach..., p. 172, A.M. Świątkowski, op.cit., p. 341.

11 A.M. Świątkowski, op.cit., p. 341.

12 A. Kalisz, A. Zienkiewicz, op.cit., p. 54. 
skill is defined as "active, attentive listening", enabling the parties to express their views. In addition, the mediator should also have skills in summarising, that is, remembering and presenting facts. Another skill that is useful in the mediation process is establishing a relationship with the conflicting parties by creating an atmosphere of trust and security and giving the parties the opportunity to make decisions at their own pace. The mediator should also help the parties to communicate and listen to each other, ensure that the mediation does not deviate from the subject, remain impartial and fair, refrain from judging the parties and favouring any of them. Effective mediation also requires problem-solving skills to help the parties clarify the most important issues that can be resolved through mediation. The mediator's ability to deal with conflict situations is also important in order to ensure that the parties remain calm during the mediation. This calmness is necessary because the parties are likely to be emotionally driven and it is therefore essential that the mediator encourages them to communicate with each other ${ }^{13}$.

The Act on the Resolution of Collective Disputes does not provide an answer to the question of whether a mediator should be a natural or a legal person. It seems that this function should be performed by a natural person, as it would be difficult for the parties to the dispute to attribute the attribute of impartiality to a collective body ${ }^{14}$. Institutions providing legal or mediation services undoubtedly have specialised staff with the knowledge necessary to conduct mediation, but it is questionable whether this knowledge alone is sufficient. It should be borne in mind that mediation takes place when the parties to a dispute have not been able to reach a consensus at the negotiation stage. The reason for the lack of agreement was not, rather, a lack of expertise in the subject matter of the dispute but an unwillingness to make concessions. The success of mediation undoubtedly depends on a number of different factors, one of which is whether the mediator enjoys the confidence of the parties, otherwise mediation is just a necessary stage on the road to declaring a strike.

When choosing a mediator, the parties may use a list of mediators drawn up by the minister responsible for labour in agreement with trade union organisations and employers' organisations meeting the criteria for represent-

13 N. Doherty, M. Guyler, op.cit., p. 20.

14 W. Masewicz, Ustawa o zwiazkach..., p. 172; B. Cudowski, Spory zbiorowe w polskim prawie pracy, Białystok 1998, p. 100. 
ativeness. This list can be particularly helpful in situations where the parties do not have any mediator candidates known to them who are knowledgeable and impartial. The Act requires that the mediator be chosen jointly by both parties to an industrial dispute, so the choice should be made by agreement between the parties. As it has already been pointed out above, the rules for carrying out this selection are established by the parties themselves and it seems that they should do it jointly ${ }^{15}$. However, if the parties fail to agree on the selection of the mediator within 5 days, further proceedings pursuant to Art. $11 \mathrm{sec} .2$ of the Act on Resolution of Collective Disputes shall be conducted by a mediator appointed, at the request of one of the parties, by the minister in charge of labour. This mediator is selected from the ministerial list.

In view of the transfer of jurisdiction over the selection of the mediator to the minister responsible for labour, the question arises as to whether the requirement to appoint a mediator is the right solution when the parties to the dispute have failed to reach agreement in this area. Or would it be more appropriate to proceed to the next stage of the collective dispute?

The optimal solution is undoubtedly an agreement between the parties as to the choice of the mediator, while the appointment of the mediator by the minister at the request of one of the parties may cause reluctance and lack of trust in the mediator on the part of the other party to the dispute. If an optimal solution is not possible, an intermediate solution should be sought, and this is what the legislator has proposed, but the question arises as to whether this is the right solution. It should be remembered that if the parties do not manage to choose a mediator within five days, we are dealing with a double conflict: over the subject of the dispute and over the person of the mediator, so the situation is complicated. Escalation of the conflict does not bode well for ending the collective dispute, as it reduces the likelihood of mediation ending in an agreement. The abandonment of solutions that make it possible to appoint a mediator by the minister means that another stage of the dispute would most probably be reached, because if the trade union party maintained its demands after the end of the negotiations it would not abandon them at the mediation stage. Moving on to the next stage of the dispute means resorting to the last resort, the strike, as it is unlikely that the parties would de-

15 A.M. Świątkowski, op.cit., p. 342. 
cide to submit the dispute to a social arbitration board. The legislator strives to maintain social peace and order, and the final method for resolving collective disputes, which is a strike, undermines this peace and order. Hence, the legislator decided to apply solutions that would allow the selection of a mediator. Undoubtedly, the legislator acted correctly, but the solutions introduced in Art. $11 \mathrm{sec} .2$ of the Act on Resolution of Collective Disputes raise doubts.

The linguistic interpretation of the provision under review suggests that the mediator is appointed by the minister at the request of one of the parties to the dispute, without regard to the other party. One would have to agree with the view presented in the doctrine that the minister should wait until both parties to the collective dispute have submitted their request for the appointment of a mediator. In such a case, the minister would withhold his decision on the selection of the mediator until each of the parties had proposed candidates, and would then select as mediator the candidate indicated by both parties ${ }^{16}$. However, this is a de lege ferenda postulate, as in the current state of the law there are no grounds for applying such a practice.

Another problem related to the selection of the mediator is the answer to the question whether the parties have the possibility of dismissing the mediator? The law does not regulate this issue, and in the doctrine there are various opinions on the subject. According to one view, since the mediator is supposed to be a shop steward for both parties, they should be able to dismiss him if he fails to meet their expectations, but this must be a decision taken by both parties ${ }^{17}$. In doctrine there is also a view that there are no grounds for the argument that the parties to a collective dispute have the possibility of dismissing the mediator whom they themselves have chosen ${ }^{18}$.

In light of the legal regulations in force, there are in fact no grounds for claiming that parties who have chosen the mediator themselves can dismiss him. Regulations concerning selection of the mediator are also incomplete, which allows us to assume that this is a deliberate move on the part of the legislator, who avoids excessive casuistry in this respect and leaves detailed arrangements to the parties to the collective dispute. However, regulations con-

\footnotetext{
16 A.M. Świątkowski, op.cit., p. 343.

17 W. Masewicz, Ustawa o związkach..., p. 174; A. Kalisz, A. Zienkiewicz, op.cit., p. 90,

18 A.M. Świątkowski, op.cit., p. 344.
} 91. 
cerning selection of the mediator were introduced by the legislator, whereas there are no provisions concerning possible dismissal of the mediator, which suggests that the legislator does not allow for such a possibility, thus the transition to the next stage of resolving collective disputes remains. It seems, however, that such statutory regulation is wrong, because the parties should be able to dismiss the mediator, since the basis for the success of mediation is trust in him. In light of the lack of appropriate statutory regulations, however, this is a de lege ferenda postulate.

The first stage of mediation is the so-called premediation, which precedes the mediation proper. This stage consists mainly of collecting the parties' consent to mediation and preparing the mediation programme. As part of the preparation of the mediation, the mediator should establish the interests and expectations of the parties and collect the data necessary for further mediation. The second stage is to open the mediation session by explaining to the parties what mediation is about. This is followed by a presentation of the parties' positions, allowing the mediator to gather information so as to identify the expectations of each party. This gives the parties a chance to verbalise their expectations, which is helpful for further stages of mediation. The next stage of model mediation is problem definition, where the mediator asks the parties questions about their expectations and then makes a so-called conflict diagnosis, i.e. defines the type of conflict. The exchange of proposals and their verification, which is the next stage of mediation, should lead to negotiations between the parties. Working out a common solution, at which a summary drawn up by the mediator can be helpful, enabling the parties to repeat what they have agreed and eliminate possible misunderstandings ${ }^{19}$. Drawing up an agreement is the final stage of mediation (in the case of court mediation it is the conclusion of a settlement agreement, in the case of collective disputes it is not only signing of an agreement but also signing of a protocol of divergences). The last stage of mediation is closing the mediation session, that is making technical arrangements concerning putting the agreement into effect ${ }^{20}$. The above-mentioned stages of mediation are model stages, so the practice of conducting mediation can differ from them, but the mediator should be

\footnotetext{
19 J. Kamiński, Negocjacje - techniki rozwiązywania konfliktów, Warsaw 2003, p. 84-85.

20 A. Kalisz, A. Zienkiewicz, op.cit., p. 53-56.
} 
guided by the assumption that mediation is characterised by the autonomy of the will of the parties both as regards the choice of the mediator as well as the rules and procedures of mediation proceedings ${ }^{21}$.

The analysis of the provisions of the Act on Resolution of Collective Disputes allows the conclusion that the aim of the Polish legislator is to maintain social order, hence he introduces solutions to guarantee the highest possible probability of resolving collective disputes by peaceful means. This is evidenced by the introduction of two obligatory methods of dispute resolution and additionally a third voluntary one, i.e. arbitration. This solution, unique in the Polish law, is compliant with the standards arising from the international law and is a manifestation of the Multi-Steps ADR structure, i.e. a transition from less to more formalised forms with a three-step structure ${ }^{22}$. Mediation as the second stage of resolving collective disputes is, in light of statutory regulations, a more formalized method than negotiations, hence the general regulations concerning the rules of selecting a mediator, the possibility of offering expert opinions or the rules of remunerating mediators.

\section{Literature}

Aktualne zagadnienia prawa pracy i polityki socjalnej (zbiór studiów), ed. B.M. Ćwiertniak, Sosnowiec 2013.

Arbitraż i mediacja. Aktualne problemy teorii i praktyki funkcjonowania sądów polubownych i ośrodków mediacyjnych, Rzeszów 2009.

Bieliński A., Uwagi wstępne na temat mediacji [in:] Sądy polubowne i mediacja, ed. J. Olszewski, Warsaw 2008.

Cudowski B., Model rozwiązywania sporów zbiorowych [in:] Zbiorowe prawo pracy w spotecznej gospodarce rynkowej, ed. G. Goździewicz, Toruń 2000.

Cudowski B., Spory zbiorowe w polskim prawie pracy, Białystok 1998.

Doherty N., Guyler M., Mediacja i rozwiązywanie konfliktów w pracy, Warsaw 2010.

21 L. Morawski, Gtówne problemy wspótczesnej teorii ifilozofii prawa. Prawo w toku przemian, Warsaw 1999, p. 168.

22 Art. 8 Convention No. 151 MOP Convention concerming of the right to organise and procedures for determining conditions of employment in the publice service (Dz.U. 1994, No. 22, item. 78). A. Kalisz, A. Zienkiewicz, op.cit., p. 89. 
Gmurzyńska E., Mediacja $w$ sprawach cywilnych $w$ amerykańskim systemie prawnym zastosowanie w Europie i w Polsce, Warsaw 2006.

Kalisz A., Zienkiewicz A, Mediacja sadowa i pozasadowa. Zarys wykładu, Warsaw 2009.

Kamiński J., Negocjacje - techniki rozwiązywania konfliktów, Warsaw 2003.

Kmieciak Z., Mediacja i koncyliacja w prawie administracyjnym, Kraków 2004.

Kowalczyk A., Mediacja i arbitraż jako pokojowe metody rozwiązywania sporów zbiorowych pracy [in:] Arbitraż i mediacja. Aktualne problemy teorii i praktyki funkcjonowania sądów polubownych i ośrodków mediacyjnych, Rzeszów 2009.

Kowalczyk A., Mediacja jako przykład pokojowej metody rozwiązywania sporów zbiorowych [in] Aktualne zagadnienia prawa pracy i polityki socjalnej (zbiór studiów), ed. B.M. Ćwiertniak, Sosnowiec 2013.

Kowalczyk A., Pojęcie sporu zbiorowego oraz pokojowe metody jego rozwiązywania w prawie polskim, Rzeszów 2017.

Kowalczyk A., Rola mediatora w sporach zbiorowych [in] Prawo pracy. Refleksje i poszukiwania. Księga Jubileuszowa Profesora Jerzego Wratnego, ed. G. Uścińska, Warsaw 2013.

Masewicz W., Ustawa o zwiazkach zawodowych. Ustawa o rozwiązwaniu sporów zbiorowych, Warsaw 1998.

Masewicz W., Zatarg zbiorowy pracy, Bydgoszcz 1994.

Morawski L., Główne problemy współczesnej teorii i filozofii prawa. Prawo w toku przemian, Warsaw 1999.

Morek R., Razem czy osobno: uwagi o znaczeniu pojęć mediacji i koncyliacji [in:] Sądy polubowne i mediacja, ed. J. Olszewski, Warsaw 2008.

Pisarczyk Ł., Spory zbiorowe [in:] System prawa pracy, t. V: Zbiorowe prawo pracy, ed. K.W. Baran, Warsaw 2014.

Prawo pracy. Refleksje i poszukiwania. Księga Jubileuszowa Profesora Jerzego Wratnego, ed. G. Uścińska, Warsaw 2013.

Sady polubowne i mediacja, ed. J. Olszewski, Warsaw 2008.

System prawa pracy, t. V: Zbiorowe prawo pracy, ed. K.W. Baran, Warsaw 2014.

Świątkowski A.M., Ustawa o rozwiązywaniu sporów zbiorowych [in:] Zbiorowe prawo pracy. Komentarz, eds. J. Wratny, K. Walczak, Warsaw 2009.

Wach A. Alternatywne formy rozwiązywania sporów sportowych, Warsaw 2005.

Wach A., Delimitacja mediacji i koncyliacji jako samodzielnych form ARD, "Radca Prawny" 2005, No. 2.

Zbiorowe prawo pracy w społecznej gospodarce rynkowej, ed. G. Goździewicz, Toruń 2000. Zbiorowe prawo pracy. Komentarz, ed. J. Wratny, K. Walczak, Warsaw 2009.

Żurawska A., Mediacja jako nowa metoda rozwiązywania sporów z zakresu prawa pracy [in:] Sądy polubowne i mediacja, ed. J. Olszewski, Warsaw 2008. 